\title{
Art, Gentrification and Regeneration - From Artist as Pioneer to Public Arts
}

\author{
STUART CAMERON \& JON COAFFEE \\ Global Urban Research Unit, University of Newcastle, UK
}

\begin{abstract}
The role of art and the artist has played a part in both of the main long-established theories of gentrification, looking respectively at 'culture' and 'capital' as key drivers. Cultural analyses of gentrification have identified the individual artist as an important agent in the initiation of gentrification processes in old working-class neighbourhoods. Alternative theorizations have recognized a second stage where capital follows the artist into gentrified localities, commodifying its cultural assets and displacing original artists/gentrifiers. The paper will argue that more recently a third key model of gentrification can be recognized where the main driver of gentrification is 'public policy' which seeks to use 'positive' gentrification as an engine of urban renaissance. This involves the use of public art and cultural facilities as a promoter of regeneration and associated gentrification.

This will be examined in relation to the arts-led regeneration strategy adopted in Gateshead in north-east England and critique whether the linking of art, regeneration and gentrification as public policy can be extended beyond the usual 'Docklands'-style localities of urban renaissance. In particular, it will consider whether this might play a role in the transformation of unpopular and stigmatized urban neighbourhoods and the renewal of urban housing markets.
\end{abstract}

KEY WORDS: Arts policy, regeneration, United Kingdom

\section{Introduction}

The role of art and the artist has played a part in both of the main long-established theories of gentrification, looking respectively at 'culture' and 'capital' as the key driver of the process. Cultural analyses of gentrification identified the individual artist as an important agent in the initiation of gentrification processes in old workingclass neighbourhoods. Alternative theorizations, emphasizing the role of property capital, traced a second stage where capital follows the artist into gentrified localities, commodifying its cultural assets and displacing the original artist/gentrifiers.

The paper-having outlined this starting point - will argue that more recently a third key model of gentrification can be recognized and, that in this too, the link to art may

Correspondence Address: Stuart Cameron, Global Urban Research Unit, School of Architecture, Planning and Landscape, Claremont Tower, University of Newcastle, Newcastle upon Tyne NE1 7RU, UK. Email: S.J.Cameron@ncl.ac.uk

ISSN 1461-6718 Print/1473-3629 Online 05/010039-20 (C) 2005 Taylor \& Francis Group Ltd DOI: $10.1080 / 14616710500055687$ 


\section{S. Cameron \& J. Coaffee}

play an important role. In this third model the main driver of gentrification is public policy, seeking to use 'positive' gentrification as an engine of urban regeneration. This includes the use of public art and cultural facilities, sponsored by local government and other public agencies, as a promoter of regeneration and associated gentrification. This will be examined in particular in relation to the arts-led regeneration strategy adopted by Gateshead Metropolitan Borough Council in north-east England and its subsequent housing and gentrification effects.

The paper will use the relationship with art as a 'marker' to trace the evolving character and modes of explanation of gentrification, in particular highlighting emerging arenas of gentrification. It will discuss whether the linking of art, regeneration and gentrification as public policy can be extended beyond the usual 'Docklands-style' localities of urban renaissance. In doing so, it will seek to unpack the different strands of urban regeneration policy, especially as they have developed in the UK since 1997 under the 'New Labour' government. In particular, it will consider whether this linkage might also play a role in the transformation of deprived, unpopular and stigmatized social housing neighbourhoods and the renewal of low-demand housing markets.

\section{The Artist as Pioneer of Gentrification}

The role of the artist as a pioneer of gentrification is perhaps most strongly associated with the work of David Ley. Ley has been regarded as one of the leading proponents of the 'demand-side' model of gentrification which focuses on the agency of the gentrifier (Beauregard, 1986) and in particular on the cultural and aesthetic values of the 'new middle class' as the mainstay of the gentrification process (Ley, 1996).

In such processes Ley (1996, p. 191) suggests that the 'urban artist is commonly the expeditionary force for the inner-city gentrifiers', and the 'advancing or colonising arm' of the middle classes. What the artist par excellence provides as an engine of gentrification is cultural capital which identifies and utilizes the attraction of devalorized inner-urban residential zones. In part, this involves an aesthetic valorization of the urban fabric of decayed historic neighbourhoods:

It is the aesthetic eye that transforms ugliness into a source of admiration ... Such an aesthetic sensibility is found particularly among social groups rich in cultural capital but poor in economic capital. At the core of such groups is the urban artist. (Ley, 1996, p. 301)

What the artist values and valorizes is, though, more than the aesthetics of the old urban quarter. The society and culture of a working-class neighbourhood, especially where this includes ethnic diversity, attracts the artist as it repels the conventional middle classes. Identification with the dispossessed, freedom from middle-class convention and restraints, and the vitality of working-class life have all long been associated with the artistic, bohemian lifestyle (Caulfield, 1994). 
Ley suggests that the artist is the pioneer for a specific fraction of the middle classes: a 'new middle class' - professionals in the media, higher education, the design and caring professions, especially those working in the state or non-profit rather than the commercial sector - that he also refers to as the 'new cultural class' (Ley, 1996, p. 15). He further argues that members of this class fraction are close to the artist in values:

The aesthetic appropriation of place ... appeals to other professionals, particularly to those who are also higher in cultural capital than in economic capital, and who share something of the artist's antipathy towards commerce and convention. (Ley, 2003, p. 2540)

The references to 'cultural' rather than 'economic' capital point to another aspect of the appeal of disinvested inner city neighbourhoods to the artist - the availability of low-cost accommodation for living and working. Here, too, the new middle class, with limited incomes and capital, and shared interests, contribute their 'sweat equity' their own labour in the work of renovation - to the renewal of the neighbourhood.

While Ley has provided a generalized argument for the importance of the role of the artist in gentrification, it is set above all in the context of a particular timethe late 1960s and 1970s - and within a particular political and cultural context of radical, student-based protest and the development of a counter-culture which underpinned the value and attitudes of the 'new middle class' (Ley, 1996, p. 2003). It also coincides with what is widely recognized as the 'first wave' of gentrification (Hackworth \& Smith, 2001) of the kind first noted by Glass (1964), involving the small-scale, autonomous (if sometimes facilitated by state aid for housing renewal, etc.) movement of individual middle-class households into old, working-class inner city neighbourhoods.

Following Lees (2000), who suggests the need to understand the sociology of the gentrification researcher, the work of Ley clearly reveals his empathy, above all, with the urban artist but also with the new middle classes and the 'conviviality' of the communities they created through gentrification. But there is, too, awareness that the process which the urban artist sets in motion may destroy what their 'aesthetic eye' values. As Ley notes:

Herein lies a paradox of gentrification. The argument for historic preservation conceals the fact that with gentrification almost nothing is preserved. The original households are replaced and the meaning of the structure is redefined from a working-class use value to an aestheticised symbolic value. (1996, p. 310)

Indeed, Ley's work traces a gentrification cycle whereby gentrifiers with high cultural/low economic capital are replaced by those with high economic capital. However, what Ley (2003) terms 'the relations between art, aestheticisation and commodification in the residential landscapes of the creative city' (p. 2528) are perhaps more 


\section{S. Cameron \& J. Coaffee}

commonly linked to supply-side explanations of gentrification which emphasize the role of capital rather than of the gentrifier.

\section{The Commodification of Art in Gentrification}

Hackworth and Smith (2001), in setting out a temporal model of three waves of gentrification, suggest that the second of these waves lasted 'almost to the end of the $1980 \mathrm{~s}$ ' and 'was characterised by the integration of gentrification into a wider range of economic and cultural processes at the global and national scale' (pp. 467-468). They exemplify this through experiences in New York where they note 'the presence of the arts community was often a key correlate of residential gentrification, serving to smooth the flow of capital into neighbourhoods, (p. 467).

While the work of Neil Smith $(1979,1986)$ provides the most powerful general account of the role of capital in a more generalized process of gentrification, the specific role of arts and the artist in 'second-wave' gentrification is most associated with Sharon Zukin's analysis of the SoHo district of Manhattan and the development of the artist loft and of loft living (Zukin, 1988).

Though Zukin's work is widely acknowledged for the lasting contribution it made to the corpus of gentrification research, gentrification as such is not its key concern. Loft Living did trace a process of successive waves of residential occupation involving, first, the conversion by artists to living and working spaces of former industrial buildings and, subsequently, the attraction of a higher income middle class seeking to enjoy a 'loft-living' lifestyle. However, for Zukin the 'real victims of gentrification through loft living are not residents at all' $(1988$, p. 5) but rather the small-scale industrial and commercial firms and their workers whose premises were converted to residential use. It was the transformation of the urban economy and the growing domination of commercial over industrial capital within the city which was her central theme.

The artist was presented as a 'stalking horse' for the needs of investment capital to revalorize urban neighbourhoods. The commodification of the artistic milieu by property and investment capital takes advantage of the 'aesthetic conjuncture' in which 'artists' living habits became a cultural model for the middle classes, and ... old factories became a means of expression for a 'post-industrial' civilisation' (Zukin, 1988, p. 15).

While a process of displacement of the original artist colonizers of New York lofts by wealthy incomers is described, Zukin is at pains to emphasize that hers was not a narrative of the artist as 'heroic victim'. Rather, the artist was viewed with much greater ambivalence as implicated in the gentrification process. Moreover, the period was characterized by the transformation of the role of the artist through commercial and state sponsorship and the artist's effective incorporation into a professionalized middle class, so that 'in the case of lofts, the social class distinction between old (artist) residents and new (non-artist) residents are somewhat blurred' (ibid., p. 5). 
In contrast, Ley (2003) has continued to reflect his empathy for the artist in suggesting that, despite state and commercial sponsorship, artists' incomes have remained low and that 'artists must be enduring considerable sacrifice of both housing quality and affordability to maintain their residential habit' (p. 2534). He also provides evidence of their continued displacement by subsequent gentrification.

Zukin's primary concern is not the displacement of the artist but the commodification of art and its milieu into an 'artistic mode of production' (1988, p. 176) which she sees as representing a strategy by large-scale investors linking accumulation and culture. In her subsequent work this process of transformation in urban economies and their balance of economic power is chronicled (Zukin, 1991) together with an analysis of culture in emerging systems of accumulation and economic power (Zukin, 1995).

Ley's and Zukin's works come together in their scathing views on the loss of authenticity and integrity in the process of commodification of art and culture through gentrification. Zukin (1991) looks at the phenomenon of Disneyland, and implies that there is little to choose between Disneyland and the commodified artist and cultural milieu of gentrified urban neighbourhoods - reporting, for example, the description of SoHo as a 'Disneyland for the aesthete' (Zukin, 1988), and analysing both Disneyland and gentrification as simply two examples of the 'circuits of cultural capital' (Zukin, 1991). Ley, too, has attacked the loss of authenticity as economic follows cultural capital; again reflecting on the paradoxes of the cycles of gentrification as commodification destroys the appeal of gentrified neighbourhoods to the artist:

... spaces colonised by commerce or the state are spaces refused by the artist. But as scholars know, this antipathy is not mutual; the surfeit of meaning in places frequented by artists becomes a valued resource for the entrepreneur. (Ley, 2003, p. 2535)

\section{Third-Wave Gentrification}

Following debates over whether gentrification was in decline in the recession of the early 1990s (Badcock, 1993; Bourne, 1993), there has been wide agreement that the assumed demise of gentrification was premature and that the phenomenon has entered a third wave of 'post-recession' gentrification which has 'the full weight of private-market finance' behind it (Smith, 2002, p. 443).

In arguing for a third wave of post-recession gentrification, Hackworth and Smith (2001) suggest that the evolution of gentrification into a generalized strategy of capital accumulation seen in the second wave extended and intensified in this third wave. As Smith further notes:

What marks the latest phase of gentrification in many cities, therefore, is that a new amalgam of corporate state powers and practices has been forged in a more ambitious effort to gentrify the city than in earlier ones. (2002, p. 443) 


\section{S. Cameron \& J. Coaffee}

Smith's work also suggests that this aggressive expansion of gentrification by capital is increasingly detrimental to the interests of low-income urban residents, an argument encapsulated in his concept of the 'revanchist city' (Smith, 1996) in which capital takes revenge on the proletariat for the post-war, welfarist settlement, recapturing the city for the middle classes and the market.

Smith (2002) argues that 'retaking the city for the middle classes' (ibid., p. 443) is not just about the creation of gentrified houses and that 'third wave gentrification has evolved into a vehicle for transforming whole area into landscaped complexes that pioneer a comprehensive class-inflected urban re-make' (ibid., p. 443). These new complexes, he notes, are based on 'recreation, consumption, production and pleasure as well as residence' (ibid., p. 443).

This intensification of capital accumulation through gentrification has, it is suggested, included an increased commodification of art and 'valorization of cultural capital' as 'resurgent neo-liberal economics and a harsher, more individuated civil society has appropriated cultural production' (Ley, 2003, p. 2542). This has in turn intensified the loss of authenticity:

... movement from festivals to festival markets, from cultural production to cultural economies, to an intensified economic colonisation of the cultural realm, to the representation of the creative city not as a means of redemption but as a means of economic accumulation. (ibid., p. 2542)

It is a process which has also been described as the 'hard-branding' of the cultural city (Evans, 2003).

\section{The Geography Of Third-Wave Gentrification}

While the political economy approach of Smith provides both an overarching explanation and a generalized picture of recent gentrification, Lees (2000) suggests that there is a need for a 'geography of gentrification' which addresses the specificity of locality. Van Criekingen and Decroly (2003) have also challenged the notion of a single end-point to a 'stage model' of gentrification and instead, in relation to their comparison of Brussels and Montreal, suggest a typology of different forms of gentrification, while recognizing that the typology they described is not itself exhaustive.

Lees's own work examines a specific element of third-wave gentrification suggested as a feature only of a limited number of global cities - what she refers to as 'super-gentrification' (Lees, 2003a). This process - analysed by Lees in the Brooklyn Heights area of New York - involves the super-rich displacing an earlier generation of what Lees refers to as 'first stage (sweat equity) gentrifiers' (2000, p. 398). In this process of 're-gentrification' the cultural, new middle class is typically displaced by those employed in the financial sector - a process which has been alternatively termed 'financification' (Lees, 2000, p. 398). Financial capital as the most powerful 
element in contemporary capital endows individuals with the resources to accomplish super-gentrification, providing what Lees (2003a) describes as a '. . . concrete manifestation of sometimes rather abstract claims made about the relationship between global economic and urban-scale processes' (p. 2491).

One driver of Lees's demand for a detailed geography of gentrification is its geographical spread, both internationally and to lower-order cities and urban areas. Again there is wide agreement that this is a key feature of the evolution of gentrification, characteristic of the second wave but intensifying still further in the third wave. Linked to its geographical extension, there is an acknowledgement that recent patterns of gentrification have also involved an enhanced role for the state. This involvement of public policy and investment has tied gentrification more explicitly to the agenda and language of urban regeneration and what is referred to in UK urban policy as 'urban renaissance' (Rogers, 1999; DTLR, 2000; Atkinson, 2002; Lees, 2003b).

These features of post-recession gentrification are incorporated by Hackworth and Smith (2001) into their argument that this phase represents an extension of the global reach and power of capital in promoting gentrification (see also Smith, 2002). They note that:

...the process becomes common in smaller, non-global cities during the 1980s.... intense struggle occurs during this period over the displacement of the poorest residents (Hackworth \& Smith, 2001 p. 467)

... many cities have embarked on a partnership with capital that exceeds even the pro-business 1980s (ibid., p. 470).

However, looking at the geography of gentrification within the UK, while its geographical extension is apparent, the assumptions underlying this general statement of causes and effects might be challenged in specific localities.

First, the reference to 'struggle over the displacement of the poorest residents' is, in most UK provincial cities, an irrelevance as middle-class incomers to the inner city have, to date, mostly been accommodated in new-build developments on former industrial land, or conversions of old industrial or commercial buildings with no displacement of an existing residential population.

Second, the model of commercial capital as the engine and instigator of the processes leading to gentrification is, at least, a simplification. Especially in those cities most affected by de-industrialization where the need for regeneration is most pressing, private capital has typically to be dragged 'kicking and screaming' into devalorized urban locations through the initiative and investment of the public sector. Of course, the dominance of neo-liberal orthodoxy in public policy at national level severely constrains the local state which is debarred from traditional welfarist responses to urban problems and obliged to court the private sector. Nonetheless, in these localities the immediate driving force of regeneration-based gentrification is the public sector in the form of both the central and the local state. Nor can the proposition that 
the attraction of a middle-class population to inner urban areas may actually deliver positive public policy outcomes and benefits for the urban community be dismissed out of hand.

Comparing, in particular, the super-gentrified neighbourhoods of a global city such as London or New York with de-industrialized provincial cities - represented in the detailed case study below by Newcastle/Gateshead - a core and periphery model of the geography of gentrification suggests itself. At the core, the driving force of commercial capital is directly manifested in its search for investment opportunities and in the agency of the financifiers. The finance sector may also play a role in gentrification processes in some lower-order cities (Dutton, 2003), but as gentrification washes out from core to periphery there is, in general, a shift in the balance of causal process with public policy responding to the need for regeneration growing in salience as a driver and initiator of the gentrification process.

\section{Art and Regeneration in Third-Wave Gentrification}

Returning more directly to the linkage of art and gentrification, both art and culture, and gentrification have been extensively used in public policy as instruments of physical and economic regeneration of declining cities, and the two are often associated in a relationship of mutual dependence. This has brought a further evolution in the nature of the linkage between art and gentrification. In the first wave this involved the creation by artists of a milieu for the production of art, and in the second wave the commodification and private consumption of this artistic milieu. The emphasis in the third phase, with the more explicit public-policy engagement and link to regeneration, is on the public consumption of art, through public art and artistic events, and particularly through the creation of landmark physical infrastructure for the arts, such as galleries, museums and concert halls.

In the UK, public policy has begun, albeit slowly, to appreciate the potential value of art and culture for both social and economic regeneration (Social Exclusion Unit, 2001). The recent competition in the UK for European Capital of Culture 2008 was a case in point in which numerous cities competed for this prize with all bids highlighting the potential of art and culture as a tool of wide-scale urban renaissance, social inclusion and neighbourhood renewal. The cities bidding for this award drew on models of a number of successful European and North American examples of arts and cultural quarters which have sprung up in hitherto redundant commercial spaces in predominantly waterfront or 'edge of city' sites creating 'symbolic capital' through constructing a distinctive' post-modern' urban aesthetic (see, for example, Harvey, 1990).

Probably the most significant example for the case study below is the experience of Bilbao and the impact of the Guggenheim Museum, generating what has been referred to as the 'Bilbao bounce' for a declining industrial city (Staples, 2004, p. 32; see also Plaza, 2000). There has been, though, substantial critical assessment of the 
'Guggenheim effect' (Rodriguez et al., 2001), including critical assessment of the potentially exclusionary and polarizing nature of its gentrification effects (Vicario \& Martinez Monje, 2003).

The case study outlined below examines the less well-known but no less striking example of arts-based regeneration in the town of Gateshead in the north-east of England, and uses this as a basis for discussing the evolving relationship between art and gentrification and wider aspects of urban regeneration. It emphasizes the central role of public-sector initiative in instigating an arts-led process of regeneration and gentrification.

\section{Art, Regeneration and Gentrification: The Case of Gateshead}

Gateshead is a former industrial metropolitan borough with a population of around 190,000. The population has declined at a steady rate in recent years linked directly to closures in traditional industries associated with mining, heavy engineering and manufacturing, such as glass making. Though post-industrial recovery as a result of new types of commercial activity, such as call centres, computer services, telecommunications and, more recently, cultural industries, has managed, to some extent, to stem migration from the area, population decline is still at a rate of around 1,200 per annum. Industrial decline has also left a legacy of derelict and contaminated land, high levels of unemployment and a host of associated social issues.

Over the past 30 years the Gateshead has attempted to use art in stimulating urban regeneration programmes. In time, this has seen art developing as a driver of regeneration, initially from small locally focused initiatives and more recently towards borough-wide schemes of international standing. Currently, an arts and cultural quarter on the 'South Bank' of the River Tyne has been used as a catalyst for significant new housing developments involving, in some cases, the attraction of a relatively high-income, middle-class population, as well as being linked to neighbourhood and housing renewal schemes in adjacent disadvantaged areas.

Gateshead attempts at urban regeneration have often been played out through its relationship with its neighbour Newcastle upon Tyne, the regional capital of the north east of England, which it faces across the River Tyne. Historically, Gateshead has lived in the shadow of Newcastle (Hickling, 2002). Newcastle is the centre of the region's commercial and cultural life; a city with a fine heritage of historic buildings and quarters and with a recent reputation for its lively and vibrant lifestyle (Chatterton \& Hollands, 2003). In contrast, Gateshead has always been seen as the poor relation - an ugly, workaday town with little to recommend it. For example, in the 1930s the writer J. B. Priestley famously condemned Gateshead with the comment that, 'the whole town appeared to have been planned by an enemy of the human race' (English Journey, 1934). The addition in the 1960s of flyovers, tower blocks and concrete town-centre redevelopments did little to increase its charm. 
Until recently, Gateshead and Newcastle maintained separate identities (Urbed, 2002). Though both shared the experience through much of the twentieth century of de-industrialization and decline, Newcastle had tended to gain most from past national regeneration programmes. In particular, in the 1980s the north bank of the River Tyne in Newcastle underwent significant transformation as part of the 'property-led' approach to regeneration of the Tyne and Wear Development Corporation (TWDC), whose boundaries excluded the southern bank of the river in Gateshead.

\section{The Long-Term Art and Public Space Strategy in Gateshead}

While the TWDC was transforming the landscape on the north bank of the Tyne at a cost of around $£ 170$ million ( 250 million euros), Gateshead Council were developing a public arts programme to 'add value' to individual and small-scale regeneration projects and to encourage private-sector regenerators to work in partnership with the local state. The focus was very much upon the softer infrastructure of regenerationthe social and community benefits of art which might initiate the gentrification process, through locally induced neighbourhood renewal.

Gateshead's 'Art in Public Places Programme' began in 1986 and was an innovative collaboration between public and private sectors in developing large-scale 'environmental sculptures' and 'decorative artwork' often linked to industrial heritage and traditional ways of living. The aim of this programme was to enhance the overall landscape architecture in the borough and to enhance the social and community benefits of arts-based regeneration. For example, art was also used in far more invisible ways as a means of environmental improvement and in stimulating social and community regeneration, such as numerous programmes of artist's residencies and educational initiatives which linked professional artists with the community, local schools and care centres.

This programme was further stimulated by the 1990 Garden Festival at Gateshead one of a national programme of Garden Festivals - which gave an active audience to numerous pieces of displayed artwork. The legacy of this programme is more than 30 major public works by leading artists. Art was also used in a public-policy setting to help reclaim derelict areas through the creation of the award-winning Riverside Sculpture Park on the banks of the River Tyne which rejuvenated a derelict industrial site into a public park incorporating a number of artworks.

This imaginative but by no means unique (Miles, 1997; Hall \& Robertson, 2001) public art and regeneration strategy 'changed gear' in the second half of the 1990s into what might be called its 'second phase' with the construction of the Angel of the North. In 1994 Gateshead Council commissioned the internationally renowned sculptor Anthony Gormley to create the Angel of the North which was unveiled in 1998. The Angel was a landmark monumental structure with open arms to greet visitors as they enter the borough from the south. It represented a change of scale of the work itself and the investment involved - the cost was $£ 800,000$ (1.2 m Euros). 
With this went an increase in financial risk - there were many local voices protesting at the folly of spending large sums of money on an artwork in the face of the pressing social needs of the borough. The outcome, though, was undoubtedly a step change in the impact of the long term arts-led regeneration strategy. The Angel of the North is probably the best-known and most instantly recognizable modern artwork in Britain, with an iconic status at national and even international level.

\section{Art as Re-Imagined Policy for Urban Renaissance: Gateshead Quays}

In the late $1990 \mathrm{~s}$, plans were put in place to develop what might be called the 'third phase' of the Gateshead strategy: an international-renowned arts and cultural facility on the Gateshead side of the River Tyne. There is little doubt that this would not have been possible without the long gestation of the strategy. Since the mid-1980s when art and culture were identified as the key to Gateshead regeneration the local authority has developed a long-term vision for the area and created a development climate where 'things get done' (Biles, 2002). The council have embraced new ways of thinking about the potential of art and culture as regeneration catalysts focusing on, first, building the confidence of a town and, then, of developers, through careful partnership working. Gateshead has also gradually built the reputation and credibility of the town as a centre for the arts in the minds of funders and investors and of the arts community.

Two major developments form the core of the Gateshead Quays' cultural quarterthe Baltic Art Gallery and the Sage Centre for Music and Performing Arts. The Baltica 1950s flourmill - has been converted into a gallery for the exhibition and production of contemporary visual art which opened in 2002, while further along the quayside is the impressive glazed façade of the Norman Foster-designed Sage Music Centre, completed in 2004. The cost is estimated at $£ 70$ million (105 million euros). Many have argued that Gateshead has been put on the international map, being referred to as a 'culture Mecca' with art as 'the region's most promising engine of growth' (Radcliffe, 2002, p. 1, see also Dailey, 2002; Ward, 2002).

Both buildings also add striking new elements to the assemblage of new construction that now reflect the regeneration of the quaysides on both banks of the Tyne. The other crucial element in this assemblage was the construction of the Millennium Bridge - a pedestrian link creating a circuit between the 'primed' Gateshead Quays and its already developed Newcastle counterpart. This iconic structure, the 'blinking eye' bridge, opened in 2001 and won the Stirling Prize as 'Building of the Year'.

The physical linkage of the bridge has to an extent been mirrored by a new policy partnership between Gateshead and Newcastle with the formation of The Newcastle Gateshead Initiative (TNGI) to promote the (ultimately unsuccessful) European Capital of Culture 2008 bid, as well as promote more generally the regeneration of 'Central Tyneside'. It must be said, however, that the key arts developments, and the Millennium Bridge itself, are entirely the product of the initiative of Gateshead 


\section{S. Cameron \& J. Coaffee}

Council, though much of the $£ 250$ million (375 million euros) investment came from national funding streams. Indeed, there is some frustration that the Baltic, the Bridge and the Angel of the North are often viewed from outside as reflecting the regeneration of 'Newcastle'.

Despite being re-imaged as an arts and cultural quarter, Gateshead Quays was very much seen as a mixed-use regeneration scheme that attempted to alter the private-sector developers' views of the particular site as well as to 'help lift the area' (Gateshead Council, 2002b, p. 13). Although the Quays development attracted major National Lottery funding, it is acknowledged that the private sector is the key to future success. The publicly funded developments have, though, been fundamental in altering the perceptions about the viability of development in Gateshead. For example, the architect who designed the new Hilton Hotel and other business complexes in the area stated that without the Baltic Art Gallery and Millennium Bridge 'none of our clients would have entertained the thought of building in Gateshead' (Smith, 2002, p. 1). Furthermore, as the leader of Gateshead Council noted at the opening of the Sage music centre, 'some years ago we would be struggling to get developers interested in any sites, but now they are interested in talking to us' (cited in Kerr, 2004).

This private development, that has flowed from the public investment, is much less original and distinctive in character - it is part of what might be thought of as the usual 'Docklands' package which dominates the Newcastle side of the River Tyne and can now be found in similar localities in most British cities. It includes new hotels, restaurants, bars and - most significant within this debate - expensive new housing. Most obviously, the skyline immediately behind the Baltic Art Gallery is now punctuated by a series of high-rise apartment blocks - known as Baltic Quays which has brought 'yuppie' housing to Gateshead.

The power of the arts-based regeneration of this area of Gateshead was strikingly evident in the fact that people queued overnight in order to pay what, in terms of the local housing market, were enormously high prices for apartments in what a few years before had been a derelict, isolated and unappealing backwater. The scheme was promoted by its developers as offering a 'new cosmopolitan way of life' with the city 'on [the] doorstep twenty four hours a day, seven days a week' (Bryant Homes, 2002). This area of the Quays has been turned into a property 'hotspot' aimed at attracting mainly affluent young professionals from the wider region, as well as nationally and internationally (see, for example, Newcastle Journal; Ives, 2002; Wilby, 2002).

The kind of regeneration seen on the Newcastle side, promoted by the TWDC, was strongly criticized as an approach which produced a commodified and 'yuppified' landscape (Byrne, 1999) that failed to address the deeper social issues manifesting in the inner areas of Newcastle. This echoed the wider critique of the Urban Development Corporation approach (see, for example, Imrie \& Thomas, 1999). It was argued, in relation to Newcastle, that, as a result, an 'urban fragment' was created on the quayside that is 'floating free from the rest of the distressed urban area' (Wilkinson, 1992, p. 207). It could be argued that, despite the difference in their drivers of regeneration, 
this landscape has now spread from the Newcastle to the Gateshead side. Indeed, the very topography seems to emphasize this 'floating free'. The River Tyne cuts between Newcastle and Gateshead in a steep-sided valley, with the new developments below its slopes. Linked and enclosed by the bridges across the river, the developments now on either side form a veritable amphitheatre of urban renaissance, but one which appears both physically and socially divorced from the urban areas beyond the slopes.

The remainder of the paper will address this critique in relation to Gateshead. Before doing so, though, it is useful to contextualize the discussion with a brief account of the different strands within contemporary urban regeneration policy in England.

\section{Urban Renaissance, Neighbourhood Renewal and Housing Market Renewal}

The recent academic debate on the link between gentrification and urban regeneration has focused almost entirely on that element of urban regeneration which, in the UK, is labelled 'urban renaissance' (Lees, 2000; Atkinson, 2002; Lambert \& Boddy, 2002).

However, from its election in 1997, the urban policies of New Labour have manifested something of a 'division of labour', with the largely physical, design-led, and economic objectives of Urban Renaissance (Rogers, 1999) balanced by the largely social objectives of the Neighbourhood Renewal Strategy (SEU, 1998).

Urban renaissance has been concerned with making the environment of cities as a whole more attractive to counter movement of people from cities and attract investment to cities. Some have even argued that this amounts to 'reinventing gentrification as urban regeneration' (Smith, 2002, p. 443). By contrast, Neighbourhood Renewal has focused on the populations of disadvantaged neighbourhood, and especially areas of social housing, rejecting the 'bricks and mortar' physical renewal of deprived estates and emphasizing instead 'people-focused' education, child development, employment, training and health policies.

To this 'twin-track' approach has been added more recently a third strand of particular importance to regeneration policies in the cities of Northern England - what is referred to as 'housing market renewal'. In response to the emergence of problems of low housing demand, vacancy and abandonment in some neighbourhoods in northern cities (Power \& Mumford, 1999) it was argued that extensive re-structuring of the physical housing stock, and of the tenure and population profile of low demand housing areas, was necessary (Nevin, 2001). The government's Sustainable Communities Plan (ODPM, 2003) announced a programme of Housing Market Renewal Pathfinders in nine urban areas in the North and Midlands of England, complementing a programme of new housing growth areas in the booming south-east. Housing market renewal brings together elements of the two other strands in that it focuses on rundown and disadvantaged urban neighbourhoods, but proposes large-scale physical renewal and seeks to promote a 'back to the city' flow of new residents. In partnership with Newcastle, Gateshead has been included as one of the Housing Market Renewal Pathfinders. 


\section{S. Cameron \& J. Coaffee}

A first point which arises from this more precise specification of the different dimensions of urban regeneration policies is that it is important to judge the impact of policies in terms of their particular objectives. As noted, urban renaissance policies are not primarily concerned with addressing the social and economic problems of disadvantaged neighbourhoods. They seek other, desirable but different, outcomes: urban containment, physical renewal, improving the vitality and quality of urban environments, and strengthening the urban economy.

As reflected in the Gateshead case, the harnessing of art to the process of publicpolicy-led gentrification has been, to date, largely limited to these 'urban renaissance' objectives. The argument put forward by local planners is that the development of Gateshead Quays into a modern residential area has succeeded in 'diversifying local housing choice'. As with similar housing on the Newcastle side (Cameron \& Doling, 1994) this housing is largely irrelevant to the need of nearby disadvantaged communities; the new housing development on the Quayside is not aimed at the indigenous population. It may, nevertheless, still represent 'positive gentrification' in delivering some of the specific objectives of urban renaissance - a renewed, revitalized and more dynamic urban core.

The question still remains, though, as to whether the arts and culture strategy, and its associated housing and gentrification effects, can impact outside of the Quayside 'amphitheatre of urban renaissance' on the adjacent area of Gateshead which contains some of the most disadvantaged neighbourhoods in the UK, with nine out of the 22 wards in this area of East Gateshead among the 'most deprived 10 per cent in England' (Gateshead Council, 2002a, p. 7).

\section{Art as a Catalyst for Wider-Scale Neighbourhood Renewal}

At one level, it has been argued that the arts-led regeneration of the Gateshead Quays has benefited the wider city through its positive impact on the external image, and the self-image, of the town as a whole (see Hetherington, 2002; Hickling, 2002).

More specifically, the regeneration of the Quays is also part of a wider development strategy which seeks to spread their impact to surrounding areas. The development of the Quays took place within the East Gateshead Regeneration Strategy (EGRS) (Gateshead Council, 1997, 2002a; see also Aston, 2001) which was developed in the mid-1990s. Within this Strategy, the catalyst of the arts and cultural quarter (and associated luxury flats) along the Quayside was explicitly linked to the development of an adjoining business park; the redevelopment of the area surrounding the nearby Gateshead International Athletics Stadium, and significant residential development to the south on the site of recently demolished housing stock in a strategically important area now known as St James' Urban Village.

The St James' Village development sought to begin to address the problems of the East Gateshead area beyond the Quays. In recent years, the housing stock and market in Inner East Gateshead has been severely hit by industrial decline and there is a poor 
quality and choice of homes and, high levels of unemployment (Gateshead Council, $2002 \mathrm{a}, \mathrm{p}$. 7). There are also very high levels of private-rented accommodation, chronic levels of negative equity and void properties with 1,600 dwellings in the area classed as 'unfit and derelict' (Gateshead Council, 2002b, p. 14). Much of the housing was in low demand in contrast with the urban renaissance occurring on the Quays a stones throw away. Following significant demolition - done in consultation and with the consent of the local community - and starting in 2001, the St James' Village development began construction in order to help meet the 'supply and demand' needs of Gateshead (Gateshead Council, 2002a, p. 8). The aim was the transformation of an area suffering from low demand into a modern, thriving mixed-income community that will contribute towards offering people a choice of homes to purchase. It is estimated that St James' Village has the potential for around 1,000 dwellings which will act to complement the improvements now planned for adjacent existing social housing estates.

These homes were intended to be affordable for local people and of good quality that will attract people back to the area. However, the evidence to date, as on the Quays, suggests that the majority of the properties have been purchased by young singles and professionals, predominantly from outside the area, with some property being bought up by investors and sold on at a higher price.

The area of St James' Village has now been incorporated within the boundaries of the Newcastle/Gateshead Market Renewal Pathfinder. The Pathfinder was announced in February 2003, with funding of $£ 69$ million (103 million Euros) confirmed later in 2003 for the first stage of what is intended to be a 15-year project. As a result of initial funding from the Pathfinder scheme, Gateshead has begun 'razing empty properties' (Schopen \& Marrs, 2003) to clear the way for new housing, and there will be further clearance of low-demand housing in adjacent areas to give way to new-style developments for which St James' Village provides a model.

There is, then, evidence that the arts and culture strategy has had an effect beyond the Gateshead Quays. This has, however, been seen as largely a 'spin-off' of the Quays development, for example through stimulating the wider housing market. There is still a question as to whether the tools of arts-based regeneration and associated gentrification can be used to more directly address the objectives not only of urban renaissance but also of neighbourhood renewal and housing market renewal in lowdemand neighbourhoods.

Re-imaging of an area or neighbourhood is a key element. Commentators such as Dean and Hastings (2000) have emphasized the importance of improving external image and self-image to the regeneration of disadvantaged neighbourhoods, and local arts-related projects can be an important tool in achieving this (Landry et al., 1996; Dwely, 2001). There is certainly awareness in Gateshead of the need for the Baltic Gallery, for example to outreach to local communities in this way. If 'image' is an ingredient of 'neighbourhood renewal' in relation to existing disadvantaged communities, it is perhaps an even more vital component of housing market renewal, seeking 


\section{S. Cameron \& J. Coaffee}

as it does to halt the drain of population from low demand areas and as part of this often to attract a new, more affluent, population to localities which may have had a negative, stigmatized image and reputation. It will be interesting to see if the experience of artsled regeneration in Gateshead will be utilized in the process of housing market renewal within the Pathfinder, for which detailed proposals are currently being developed.

The extension of an arts-based strategy, and associated gentrification, into the arena of housing market renewal does, though, bring with it some challenging normative issues. As has been argued in relation to related policies in Newcastle (Cameron, 2003), the diversification of tenure and population structure which forms an element of housing market renewal may result in gentrification which actually does involve displacement of an existing low-income population, and in the case of Newcastle this has given rise to political controversy and opposition by residents (Coaffee \& Healey, 2003).

There is a dilemma here. As has been suggested above, the 'urban renaissance' effects of gentrification through new high-cost housing in the Quayside area of Gateshead has little relevance, either positive or negative, for the low-income residents of surrounding neighbourhoods. Housing market renewal, on the other hand, does seek to directly impact on declining, disadvantaged neighbourhoods, but in doing so will utilize a combination of renewal and gentrification that involves the displacement of some residents of low-cost social and private housing.

A critical interpretation of housing market renewal might well draw on Smith's concept of the 'revanchist city' (Smith, 1996), outlined above. From this perspective, few things could be as clear-cut a reflection of revanchist gentrification undermining post-war welfarism than the insertion of middle-class home ownership into areas of social housing. The contrary argument is that a combination of radical neighbourhood restructuring and rebalancing of population, and sensitive engagement with existing communities (Mumford \& Power, 2003), can produce more liveable and sustainable socially mixed neighbourhoods to the benefit of old and new residents alike.

\section{Conclusions}

What has been achieved so far in the case of Gateshead highlights a number of lessons. First, it has demonstrated very clearly the potential power of an arts- and culture-based regeneration strategy to give rise to gentrification in what would, until recently, have been regarded as the most unlikely of locations. Second, it clearly demonstrates the central role of the public sector as a driver of this process.

Returning to the discussion of gentrification, this case study does support the idea of a third wave more extended in its geographical reach, bringing gentrification to new localities by-passed by the earlier forms of gentrification which were limited to higher order and more buoyant cities. However, it also reinforces the arguments for a variety of forms and of causal processes in different geographical contexts. In using art as a 'marker' for tracing the evolution of gentrification and its explanations, the 
case of Gateshead points strongly to the need to acknowledge, within the geography of third-wave gentrification, a model of public-policy driven gentrification typical of regenerating de-industrialized cities.

Moreover, in Gateshead the use by the local authority of the arts as a catalyst for regeneration has involved a long-term strategy which might reasonably be described in words which, in contemporary discourse, are not usually associated with the public sector, words such as: initiative, enterprise, imagination, risk and courage.

Until recently Gateshead has been seen as little more than a backwater of Newcastle. Today, on the back of arts-led regeneration, it has become one of the UK's hottest property locations. This has been made possible by a long-term, visionary and innovative approach adopted by the local state using art as a central focus of public policy. Hickling (2002) highlights that 'the scale of the cultural re-branding of Gateshead is unprecedented: while most cities would be proud to create a single, world-class cultural status symbol, Gateshead can boast four'. As Hetherington (2002) further noted:

Gateshead, once dismissed by JB Priestley as a town which appeared to have been invented 'by an enemy of the human race', decided 10 years ago that culture and the arts provided the key to a regeneration strategy ... What is happening here is unique with a combination of cultural statements, thanks to a visionary and determined council. (2002)

The case study leaves open two related questions. Can the linkage of arts, regeneration and gentrification be transplanted beyond the isolated - geographically and socially - arenas of urban renaissance typified by dockland and city centres to disadvantage and declining housing neighbourhood? And would this constitute 'positive gentrification' producing regeneration which benefits existing residents as well as newcomers?

Unlike other attempts at cultural or arts-led regeneration, Gateshead started from an aim of inclusivity and built up a reputation slowly, with the Angel of the North acting as a 'tipping' point in the process of cultural renewal' (Minton, 2003, p. 23), and has had some success in spreading the impacts of urban renaissance on the Quays through the urban area. It remains to be seen whether the approach which led to the impressive regeneration of the Quayside can be transplanted from this arena of urban renaissance to the much more challenging terrain of social renewal and housing market restructuring in the adjacent declining and disadvantaged neighbourhoods now included in the Market Renewal Pathfinder, and whether its outcome in these neighbourhoods can be the creation of more sustainable and successfully functioning mixed communities. The imaginative and sensitive approach to regeneration developed over the years in Gateshead perhaps gives some grounds for optimism that this difficult challenge might be met. 


\section{S. Cameron \& J. Coaffee}

\section{References}

Aston, R. (2001) East Gateshead Strategic Employment Area, Independent validation of the ERDF Objective 2 programme 2000-2006.

Atkinson, R. (2002) Does gentrification help or harm neighbourhoods? An assessment of the evidence base in the context of the new urban agenda. Centre for Neighbourhood Research Paper 5, Glasgow: University of Glasgow.

Badcock, B. (1993) Notwithstanding the exaggerated claims, residential revitalization really is changing the form of some western cities: a response to Bourne, Urban Studies, 30(4), pp. 191195.

Beauregard, R. (1986) The chaos and complexity of gentrification, in: N. Smith \& P. Williams (Eds) Gentrification of the City, pp. 35-55 (Winchester: Allen \& Unwin).

Biles, A. (2002) Rebranding Gateshead, Regeneration and Renewal, 15 March, pp. 16-17.

Bourne, L. (1993) The myth and reality of gentrification; a commentary on emerging urban forms, Urban Studies, 30(4), pp. 183-189.

Bryant Homes. (2002) Baltic Quay 24-7 Living.

Byrne, D. (1999) Tyne and Wear UDC - turning the uses inside out: active deindustrialisation and its consequences, in: R. Imrie \& H. Thomas (Eds) British Urban Policy - An Evaluation of the Urban Development Corporations, Second Edition, pp. 128-143 (London: Sage Publications).

Cameron, S. (2003) Gentrification, housing redifferentiation and regeneration; going for growth in Newcastle upon Tyne, Urban Studies, 40(12), pp. 2367-2382.

Cameron, S. \& Doling, J. (1994) Housing neighbourhoods and urban regeneration, Urban Studies, 31(7), pp. 1211-1223.

Caulfield, J. (1994) City Form and Everyday Life: Toronto's Gentrification and Critical Social Practice (Toronto: University of Toronto Press).

Chatterton, P. \& Hollands, R. (2003) Urban Nightscapes: Youth Cultures, Pleasure Spaces and Corporate Power (New York: Routledge).

Coaffee, J. \& Healey, P. (2003) My voice my place: tracking transformations in urban governance, Urban Studies, 40(10), 1960-1978.

Dailey, D. (2002) Stars of the Tyne'. Available at: http://www.viamichelin.com/viamichelin/gbr/jsp/ mag3/art20020901/html/Newcastle_stars.jsp (accessed 11 October 2003).

Dean, J. \& Hastings, A. (2000) Challenging Images: Housing Estates, Stigma and Regeneration (Bristol: Policy Press).

Department of Transport, Local Government, and the Regions (DTLR) (2000) Our Towns and Cities: The Future Delivering an Urban Renaissance (London: HMSO).

Dutton, P. (2003) Leeds calling; the influence of London on the gentrification of regional cities, Urban Studies, 40(12), pp. 2557-2573.

Dwely, T. (2001) Creative Regeneration: Lessons from Ten Community Arts Projects (York: Joseph Rowntree Foundation)

Evans, G. (2003) Hard-branding the cultural city - from Prado to Prada, International Journal of Urban and Regional Research, 2(2), pp. 417-440.

Gateshead Council (1997) East Gateshead: The Regeneration Strategy.

Gateshead Council (2002a) East Gateshead: The Regeneration Strategy.

Gateshead Council (2002b) Housing Strategy 2002-2005.

Glass, R. (1964) London: Aspects of Change (London: MacGibbon and Kee).

Hackworth, J. \& Smith, N. (2001) The changing state of gentrification, Tijdschrift voor Economische en Sociale Geografie, 92(4), pp. 464-477.

Hall, T. \& Robertson, I. (2001) Public art and urban regeneration: advocacy, claims and critical debates, Landscape Research, 26(1), pp. 5-26.

Harvey, D. (1990) The Condition of Postmodernity (Oxford: Blackwell). 
Hetherington, P. (2002) Baltic redefines cold Gateshead as hotspot, The Guardian Unlimited. Available at http://society.guardian.co.uk/urbandesign/story10,11200,753990,00.html (accessed 12 July 2002).

Hickling, A. (2002) When the hope comes in, The Guardian Unlimited, 24 June.

Imrie, R. \& Thomas, H. (1999) British Urban Policy - An Evaluation of the Urban Development Corporations, Second Edition (London: Sage Publications).

Ives, C. (2002) Baltic Quay Housing Development, Gateshead Quays Update, Issue 3, May.

Kerr, R. (2004) Sage latest step in towns regeneration. Available at http://new.bbc.co.uk $\backslash 1 \backslash$ hi/ england/tyne/4095103.stm (accessed 17 December 2004).

Lambert, C. \& Boddy, M. (2002) Transforming the City: Post-Recession Gentrification and ReUrbanisation, Centre for Neighbourhood Research CP6 Bristol: University of West of England.

Landry, C., Greene, L., Matarosso, F. \& Bianchini, F. (1996) The Art of Regeneration: Urban Renewal through Cultural Activity (Stroud: Comedia).

Lees, L. (2000) A reappraisal of gentrification: towards a 'geography of gentrification', Progress in Human Geography, 24(3), pp. 389-408.

Lees, L. (2003a) Super-gentrification; the case of Brooklyn Height, New York City, Urban Studies, 40(12), pp. 2487-2510.

Lees, L. (2003b) Visions of urban renaissance: the Urban Task Force report and the Urban White Paper, in: R. Imrie \& M. Raco (Eds) Urban Renaissance: New Labour, Community and Urban Policy (Bristol: Policy Press).

Ley, D. (1986) Alternative explanations of inner city gentrification; a Canadian assessment, Annals of the Association of American Geographers, 76(4), pp. 526-535.

Ley, D. (1996) The New Middle Classes and the Remaking of the Central City (Oxford: Oxford University Press).

Ley, D. (2003) Artists, aestheticisation and the field of gentrification, Urban Studies, 40(12), pp. 25272544.

Miles, M. (1997) Art, Space and the City: Public Art and Urban Futures (London: Routledge).

Minton, A. (2003) Northern Soul - Culture, Creativity and Quality of Place in Newcastle and Gateshead (London: RICS/DEMOS).

Mumford, K. \& Power, A. (2003) Boom or Abandonment: Resolving Housing Conflicts in Cities (Coventry: Chartered Institute of Housing).

Newcastle Journal (2003) Stunning penthouse enjoys a prime quayside setting, The Journal Homemaker: Property of the Week, 19 April, p. 27.

Nevin, B. (2001) Securing Housing Market Renewal: A Submission to the Comprehensive Spending Review (London: National Housing Federation).

Office of the Deputy Prime Minister (ODPM) (2003) Sustainable Communities: Building for the Future (London: HMSO).

Plaza, A. (2000) Evaluating the influence of a large cultural artefact on tourism: the Guggenheim Museum Bilbao case, Urban Affairs Quarterly, 36(2), pp. 264-274.

Power, A. \& Mumford, K. (1999) The Slow Death of Great Cities? Urban Abandonment or Urban Renaissance (York: Joseph Rowntree Foundation).

Radcliffe, L. (2002) Newcastle/Gateshead, UK from Coal to Culture. The World's New Culture Meccas. NBC News. Available at http://stacks.msnbc.com/new/798868 (accessed 16 October 2002).

Rodriguez, A., Martinez, E. \& Guenaga, G. (2001) Uneven development: new urban policies and sociospatial fragmentation in metropolitan Bilbao, European Urban and Regional Studies, 8(2), pp. 161178.

Rogers, R. (1999) Towards an Urban Renaissance: The Report of the Urban Task Force (London: E \& FN Spon).

Schopen, F. \& Marrs, C. (2003) Housing Renewal Pathfinders take first steps, Regeneration and Renewal, 17 January, p. 1. 


\section{S. Cameron \& J. Coaffee}

Smith, A. (2002) The World's New Culture Meccas: Newcastle Gateshead from Coal to Culture. Available at http://stacks.msnbc.com/news/798868asp?cpi-1 (accessed 16 October 2002).

Smith, N. (1979) Towards a theory of gentrification: a back to the city movement by capital, not people, Journal of the American Planning Association, 45, pp. 538-448.

Smith, N. (1986) Gentrification, the frontier and the restructuring of urban space, in: N. Smith \& P. Williams (Eds) Gentrification of the City, pp. 315-334 (Winchester: Allen \& Unwin).

Smith, N. (1996) The New Urban Frontier: Gentrification and the Revanchist City (London: Routledge).

Smith, N. (2002) New globalism, new urbanism: gentrification as global urban strategy, Antipode, 34(3), pp. 427-450.

Social Exclusion Unit (1998) Bringing Britain Together: A New Strategy for Neighbourhood Renewal. Command Paper 4045 (London: Cabinet Office).

Social Exclusion Unit (2001). Report of the Polity Action Team 10 - Arts and Sport (London: DCMS).

Staples, D. (2004) Cultural renewal, International Arts Manager, April, pp. 32-34.

Urbed (2002) Towns and Cities - Partners in Urban Renaissance (report for he Office of the Deputy Prime Minster).

van Criekingen, R. \& Decroly, J.-M. (2003) Revisiting the diversity of gentrification: neighbourhood renewal processes in Brussels and Montreal. Urban Studies, 40(12), pp. 2451-2468.

Vicario, P. \& Martinez Monje, P. (2003) Another 'Guggenheim effect'? The generation of potentially gentrifiable neighbourhoods in Bilbao, Urban Studies, 40(12), pp. 2383-2400.

Ward, D. (2002) Forget Paris and London, Newcastle is a creative city to match Kabul and Tijuana. Available at http://www.society.guardian.co.uk/regeneration/story/0,7940,784748,00.html (accessed 7 October 2002).

Wilby, T. (2002) Baltic Quay Today, Bryant Homes, Issue 1.

Wilkinson, S. (1992) Towards a new city? A case study of image-improvement initiatives in Newcastle upon Tyne, in: P. Healey, S. Davoudi, S. Tavsanoglu., M. O’Toole, \& D. Usher (Eds) Rebuilding the City, Property-led Regeneration, pp. 174-211 (Suffolk: St Edmundsbury Press).

Zukin, S. (1988) Loft Living: Culture and Capital in Urban Change (London: Radius).

Zukin, S. (1991) Landscapes of Power: From Detroit to Disneyland (Berkeley, CA: University of California Press).

Zukin, S. (1995) The Cultures of Cities (Oxford: Blackwell). 